\title{
Seismic Analysis of Soil-Foundation Interaction under a Bridge Pier Due to Chauk Earthquake Excitation of 0.12g to 0.5g
}

\author{
Zin May Hnin ${ }^{1}$, Nyan Myint Kyaw ${ }^{1}$, Kyaw Kyaw ${ }^{2}$ \\ 1Ph.D Candidate, ${ }^{2}$ Professor \\ Department of Civil Engineering, Yangon Technological University, Yangon, Myanmar
}

\begin{abstract}
In this study, seismic analysis of soil-foundation interaction under a bridge pier are studied with different earthquake excitations. In 2016, August 25, a magnitude of 6.8 happened near Bagan region. Pakokku Bridge, the longest of the bridges over the Irrawaddy, is situated on 37.8 miles from the epicentre of 2016 Chauk earthquake. That is why the safety performance of long-span Bridge (Pakokku Bridge) especially for the safety of the foundation system subjected to soil-foundation interaction is necessary to investigate for unexpected future seismic excitation. Firstly super structural loadings on the pile cap are estimated by using STAAD PRO V8i. And then, p-y curves are determined by Reese (1974) method for the static and National Cooperative Highway Research Program (NCHRP) for dynamic conditions. Based on the development of p-y curves, theoretical ultimate soil resistance pcr and pcd due to wedge and flow failure are determined to produce critical depth xcr. After that, finite element software ABAQUS is used for the analysis of soil-foundation interaction under a bridge pier in static condition. And then, the behaviour of soil foundation interaction under a bridge pier is carried out due to Chauk earthquake. In this study, the behaviour of soil-foundation interaction such as deflections and settlements are produced. According to the analysis results in static condition, it is found that the vertical and horizontal displacements at the pile tip are $2.28 \mathrm{~mm}$ and $0.14 \mathrm{~mm}$ respectively. In dynamic condition, the vertical and horizontal displacements at the pile tip are $3 \mathrm{~mm}$ and $2.94 \mathrm{~mm}$ are found at $0.12 \mathrm{~g}$. After that, maximum ground acceleration of $0.5 \mathrm{~g}$ is $14.5 \mathrm{~mm}$ and $2.94 \mathrm{~mm}$ in horizontal and vertical displacement of pile tip. Maximum shear stress and strain are found out the base of the pile cap. Finally it is found that the soil-foundation interaction under a bridge pier during earthquake motions presented in this study is reliable and reasonable with the limitation of AASHTO Standard Specifications for Highway Bridges.
\end{abstract}

KEYWORDS: Pakokku Bridge, Soil-foundation interaction, Abaqus, p-y curves, 2016 Chauk earthquake

\section{INTRODUCTION}

Pakokku Bridge is a rail and road bridge across the Irrawaddy River in Myanmar. The bridge is part of the IndiaMyanmar-Thailand Trilateral Highway and is the longest bridge in Myanmar. This bridge is connected to Pakokku city and the administrative district of Nyaung-U and Mindat. The construction was begun at 2009 and it was completed in 2012. Pakokku Bridge is $3.4 \mathrm{~km}$ long and $14.8 \mathrm{~m}$ in width. In 2016, a magnitude of 6.8 Chauk earthquake happened near Bagan region. Pakokku Bridge is situated on 37.8 miles from the epicentre of 2016 Chauk earthquake. Therefore, the safety performance of Pakokku Bridge especially for the safety of the foundation system subjected to soil-foundation interaction is necessary to evaluate due to seismic excitation.

When lateral loads are applied on a pile, lateral deflection of the pile depends on the soil resistance, in turn, depends on the pile deflection and this dependence is known as soil-pile interaction. Pile foundation is one of the most common and important sub-systems of the bridges. Such a foundation is commonly chosen when the construction site is a weak or saturated sandy ground. Bridge-pier foundation is important to simultaneously consider the interaction behaviour of a soil-group pile-bridge pier system when designing such a foundation. Bridge substructure is a very important part of a bridge as it safely transfers the loads from the superstructure to the earth [1]. The subgrade reaction approach provides the simplest solution for the pile-soil interaction problem. The subgrade reaction has been widely accepted in the analysis of soil-structure interaction problems. The p-y approach is another method for handling pile-soil interaction. Moreover, the finite element method (FEM) is the most powerful tool in modeling soil-structure interaction.
The research described in this paper presents a numerical investigation of composite soil-foundation system. Firstly, checking the bearing capacity of Case Study Bridge is based on Shamsher Prakash [2] and compare pier loading and pile group capacity. After that, p-y curves are determined using the subgrade reaction approach according to Reese and Matlock [6]. The soil-foundation system is modelled and analyzed using Abaqus/Cae [4].

\section{RESEARCH METHODOLOGY}

The research study included structural investigation, soil investigation, modelling and analysis for the selected case study. The flow chart of this study is shown in Fig. 1.

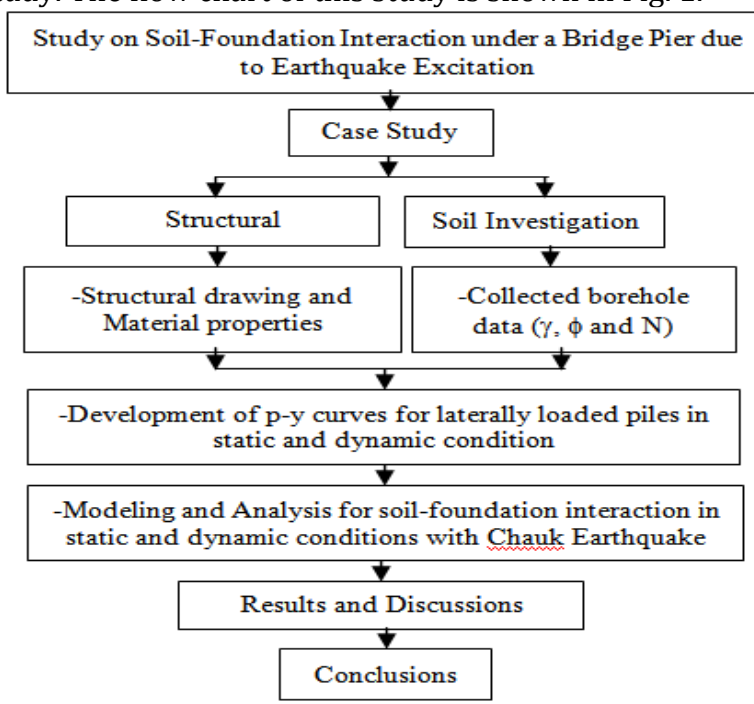

Fig. 1 Flow chart of the methodology 


\section{STRUCTURAL INVESTIGATION}

The selected case study, Pakokku Bridge is the longest bridge over the Irrawaddy River in Myanmar. It is composed of 6 main spans and 20 numbers of piers under the bridge. The superstructure of the bridge is composed of steel truss members, concrete deck slab, and I-beam girders. The behaviour of soil foundation interaction are analysed for the pier number 5 under the bridge of the middle span. The photo of Pakokku Bridge and case study of pier (PR 5) location, sectional elevation and plan view are shown in Fig. 2.

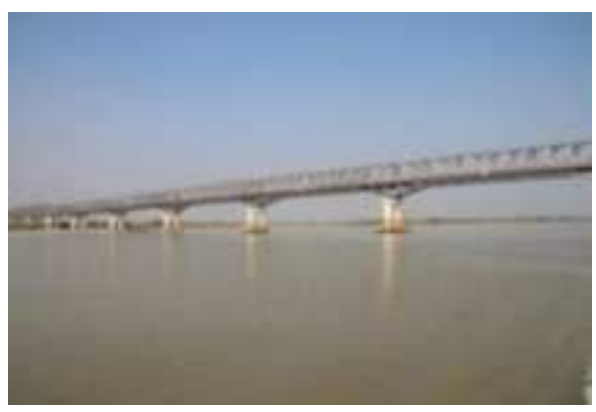

(a)

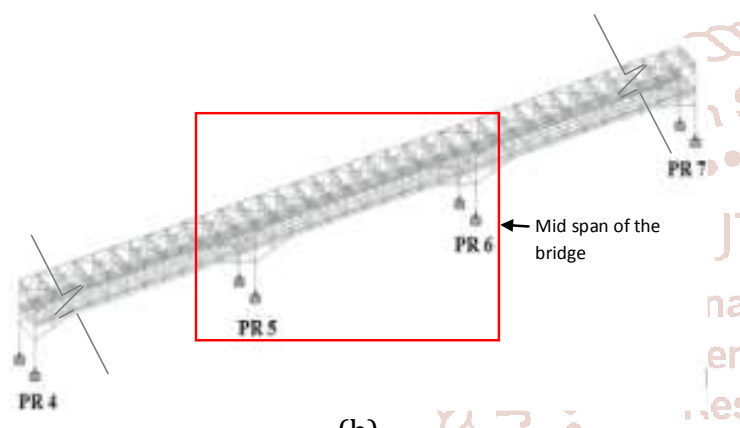

(b)

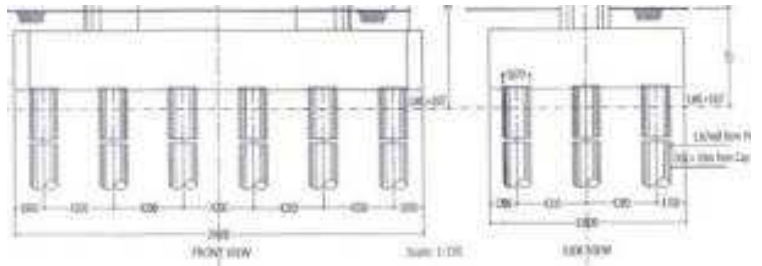

(C)

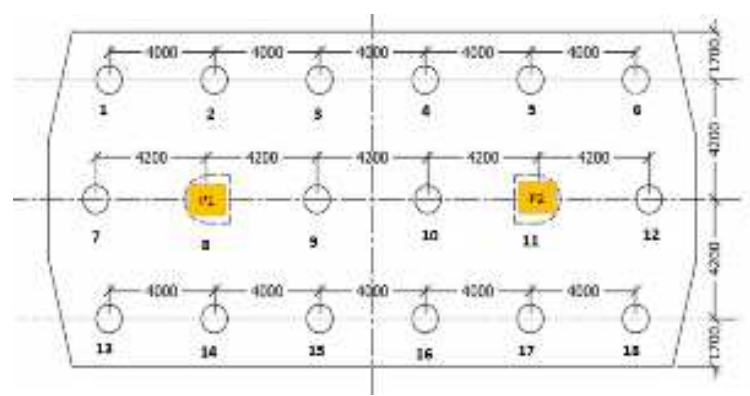

(d)

Fig. 2 (a) Pakokku bridge, (b) Study portion of Pakokku Bridge, (c) Sectional elevation of longitudinal and transverse of case study and (d) Plan view of case study (PR5)

As shown in Figs. 2 (c) and (d), pier under the bridge are composed of two column bents and supporting foundation with eighteen piles group. . So there are two loading points, pier 1 and pier 2 , on the pile cap. Table I and II present the information of pile and pile cap details, and material properties.

Superstructural loadings on the pile cap are determined according to AASHTO. The factored loading from the superstructure on the pile cap are presented in Table III.

TABLE I PILE AND PILE CAP DETAILS

\begin{tabular}{|c|c|c|c|c|}
\hline Pier No. & No. of Pile & $\begin{array}{c}\text { Pile Cap Dimension } \\
(\mathrm{m} \times \mathrm{m} \mathbf{~} \mathrm{m})\end{array}$ & Diameter of Pile (m) & $\begin{array}{c}\text { Pile Length } \\
(\mathrm{m})\end{array}$ \\
\hline 5 & 18 & $24.6 \times 11.8 \times 2.75$ & 1.67 & 18 \\
\hline
\end{tabular}

TABLE II MATERIAL PROPERTIES

\begin{tabular}{|c|c|c|}
\hline & Pier & Pile \\
\hline Design strength of concrete (MPa) & 24 & 29 \\
\hline Yield strength of re-bar (MPa) & 290 & 290 \\
\hline
\end{tabular}

TABLE III LOADING OF STRUCTURE ON THE PILE CAP

\begin{tabular}{|c|c|c|c|c|c|c|}
\hline \multirow{2}{*}{ Pier } & $F_{x}$ & $F_{y}$ & $F_{z}$ & $M_{x}$ & $M_{y}$ & $M_{z}$ \\
\cline { 2 - 7 } & $(k N)$ & $(k N)$ & $(k N)$ & $(k N-m)$ & $(k N-m)$ & $(k N-m)$ \\
\hline 1 & 0 & $2.4 \times 10^{4}$ & 8.9 & 18 & 9.3 & 1127 \\
\hline 2 & 0 & $2.7 \times 10^{4}$ & 0 & 85.2 & 8.3 & 1537 \\
\hline
\end{tabular}

\section{SOIL INVESTIGATION}

Standard penetration test SPT N values, friction angle $(\phi)$, the compressive strength of soil (c) and unit weight of soil $(\gamma)$ are important parameters to analyze the behaviour of soil-pile interaction. The properties of soil under the pier 5 are shown in Table IV. As shown in Table IV, the cohesion of soil 'c', for every layer is zero and the internal friction angles of soil are ranging from $19.5^{\circ}$ to $30.5^{\circ}$. 
TABLE IV PROPERTIES OF SOIL

\begin{tabular}{|c|c|c|c|c|}
\hline Depth $\mathbf{z},(\mathrm{m})$ & $\mathrm{N}$ & $\gamma\left(\mathrm{kg} / \mathrm{m}^{3}\right)$ & $\phi($ degree $)$ & $\mathrm{c}\left(\mathrm{KN} / \mathrm{m}^{2}\right)$ \\
\hline 3 & 10 & 1853.4 & 19.5 & 0 \\
\hline 6 & 19 & 1866.2 & 19.5 & 0 \\
\hline 9 & 30 & 1912.6 & 19.5 & 0 \\
\hline 12 & 23 & 1883.8 & 19.5 & 0 \\
\hline 15 & 25 & 1845.3 & 21.3 & 0 \\
\hline 18 & 22 & 1853.4 & 21.3 & 0 \\
\hline 21 & 25 & 1895.0 & 21.3 & 0 \\
\hline 24 & 30 & 1911.0 & 29.2 & 0 \\
\hline 27 & 29 & 1907.8 & 29.2 & 0 \\
\hline 30 & 29 & 1903.0 & 29.2 & 0 \\
\hline 33 & 55 & 1946.3 & 29.2 & 0 \\
\hline 36 & 75 & 1959.1 & 30.4 & 0 \\
\hline 39 & 88 & 1965.5 & 30.4 & 0 \\
\hline 42 & 118 & 1984.7 & 30.4 & 0 \\
\hline 45 & 124 & 2008.7 & 30.4 & 0 \\
\hline
\end{tabular}

\section{CALCULATION OF THE BEARING CAPACITY OF BORED PILE}

The bearing capacity of piles is, therefore, estimated based on initial strength and deformation characteristics of the soil. The effect of changed soil conditions are reflected in the nondimensional empirical coefficient $\mathrm{N}_{\mathrm{q}}$ and mobilized shaft friction, $\mathrm{f}_{\mathrm{s}}$, in cohesionless soils [2]. The final expression for ultimate load capacity, $\left(Q_{v}\right)_{\text {ult }}$ of a pile then becomes

$$
\left(\mathrm{Q}_{\mathrm{v}}\right)_{\mathrm{ult}}=\mathrm{Q}_{\mathrm{p}}+\mathrm{Q}_{\mathrm{f}}
$$

The ultimate end resistance $Q_{p}$ in tons of drilled or bored piles can be estimated by the following relationships

$$
\text { For Sand, } \mathrm{Q}_{\mathrm{p}}=\frac{1}{3}(0.4 \overline{\mathrm{N}} / \mathrm{B}) \mathrm{D}_{\mathrm{f}} \mathrm{A}_{\mathrm{p}} \leq \frac{4}{3} \overline{\mathrm{N}} \mathrm{A}_{\mathrm{p}}
$$

For cohesionless or nonplastic silt,

$$
\mathrm{Q}_{\mathrm{p}}=\frac{1}{3}(0.4 \overline{\mathrm{N}} / \mathrm{B}) \mathrm{D}_{\mathrm{f}} \mathrm{A}_{\mathrm{p}} \leq \overline{\mathrm{N}} \mathrm{A}_{\mathrm{p}}
$$

valuated form the basic procedure for developing p-y curves in the static condition (Reese et al., 1974) [6].

\section{A. P-y Curves of Laterally Loaded Piles in Cohesionless Soils for Static Condition}

The p-y method models a laterally loaded pile as a soilstructure interaction problem because the lateral load applied results in lateral deflection of the pile, which causes reactions in the soil. A static equilibrium between the pile and soil must be obtained. The numerical solution of the problem requires a relationship between the pile deflections and the soil reactions. Static p-y curves with different depth of soil for transverse and longitudinal directions of the pile group are developed according to Reese and Matlock [6].

Soil resistance and deflection are determined by using the following equations.

$$
\mathrm{p}_{\mathrm{cr}}=\gamma \mathrm{x}\left[\frac{\mathrm{K}_{0} \mathrm{x} \tan \phi \sin \beta}{\tan (\beta-\phi) \cos \alpha}+\frac{\tan \beta}{\tan (\beta-\phi)}(\mathrm{B}+\mathrm{x} \tan \beta \tan \alpha)\right]
$$$$
+\gamma \mathrm{x}\left[\mathrm{K}_{0} \mathrm{x} \tan \beta(\tan \phi \sin \beta-\tan \alpha)-\mathrm{K}_{\mathrm{A}} \mathrm{B}\right]
$$$$
\mathrm{p}_{\mathrm{cd}}=\mathrm{K}_{\mathrm{A}} \mathrm{B} \gamma \mathrm{x}\left(\tan ^{8} \beta-1\right)+\mathrm{K}_{0} \mathrm{~B} \gamma \mathrm{x} \tan \phi \tan ^{4} \beta
$$

$$
\begin{gathered}
\mathrm{Q}_{\mathrm{f}}=\frac{1}{2}\left(\mathrm{f}_{\mathrm{s}}\right)(\text { perimeter }) \text { (Embedment length) } \\
\mathrm{f}_{\mathrm{s}}=\frac{\overline{\mathrm{N}}}{50} \leq 1 \mathrm{tsf}
\end{gathered}
$$

$$
\begin{aligned}
\text { Where, } \alpha=\frac{1}{2} \phi, \beta=45+\alpha, \text { and } \mathrm{K}_{\mathrm{A}}=\tan ^{2}\left(45-\frac{1}{2} \phi\right) \\
\mathrm{p}_{\mathrm{m}}=\mathrm{B}_{1} \mathrm{p}_{\mathrm{c}} \\
\mathrm{y}_{\mathrm{m}}=\frac{\mathrm{B}}{60} \\
\mathrm{p}_{\mathrm{u}}=\mathrm{A}_{\mathrm{l}} \mathrm{p}_{\mathrm{c}} \\
\mathrm{y}_{\mathrm{u}}=\frac{3 \mathrm{~B}}{80} \\
\mathrm{~m}=\frac{\mathrm{p}_{\mathrm{u}}-\mathrm{p}_{\mathrm{m}}}{\mathrm{y}_{\mathrm{u}}-\mathrm{y}_{\mathrm{m}}} \\
\mathrm{n}=\frac{\mathrm{p}_{\mathrm{m}}}{\mathrm{m} \mathrm{y}_{\mathrm{m}}} \\
\mathrm{C}=\frac{\mathrm{p}_{\mathrm{m}}}{\left(\mathrm{y}_{\mathrm{m}}\right)^{\frac{1}{\mathrm{n}}}} \\
\mathrm{y}_{\mathrm{k}}=\left(\frac{\mathrm{C}}{\mathrm{n}_{\mathrm{h}} \mathrm{x}}\right)^{\mathrm{n} /(\mathrm{n}-1)} \\
\mathrm{p}=\mathrm{C} \mathrm{y} \mathrm{y}_{\mathrm{n}}^{1 / \mathrm{s}}
\end{aligned}
$$

For the solution of the problem of a laterally loaded pile, it is necessary to predict a set of $p-y$ curves. The p-y curves were 
International Journal of Trend in Scientific Research and Development (IJTSRD) @ www.ijtsrd.com eISSN: 2456-6470

where,

$\mathrm{p}_{\mathrm{cr}}, \mathrm{p}_{\mathrm{cd}}=$ theoretical ultimate soil resistance due to wedge and flow failure

$\mathrm{p}_{\mathrm{c}} \quad$ =govern theoretical ultimate soil resistance

$\mathrm{p}_{\mathrm{u}} \quad=$ ultimate soil resistance

$\mathrm{y}_{\mathrm{u}} \quad=$ deflection at ultimate soil resistance

$\mathrm{p}_{\mathrm{m}} \quad=$ soil pressure at $\mathrm{D} / 60$

$\mathrm{y}_{\mathrm{m}} \quad=$ deflection at soil pressure at $\mathrm{D} / 60$

$\mathrm{p} \quad=$ establish initial straight line portion

$\mathrm{y}_{\mathrm{k}} \quad=$ deflection at establish initial straight line portion

$\mathrm{x} \quad=$ depth below the pile head

$\gamma \quad=$ unit weight of soil

$\phi \quad=$ angle of internal friction

$\mathrm{K}_{\mathrm{o}} \quad=$ coefficient of lateral earth pressure

$\mathrm{B}=$ diameter of pile

$\alpha, \beta, K_{A}$ are necessary soil parameters for obtaining the value of $\mathrm{x}_{\mathrm{cr}}$, at the interaction of $\mathrm{p}_{\mathrm{cr}}$ and $\mathrm{p}_{\mathrm{cd}}$. The coefficients $\mathrm{B}_{1}$ and $\mathrm{A}_{1}$ are used for determining of $\mathrm{p}_{\mathrm{m}}$ and $\mathrm{p}_{\mathrm{u}}$. The critical depth value $\mathrm{x}_{\mathrm{cr}}$ is obtained by plotting $\mathrm{p}_{\mathrm{cr}}$ and $\mathrm{p}_{\mathrm{cd}}$ with depth (x) on a common scale.

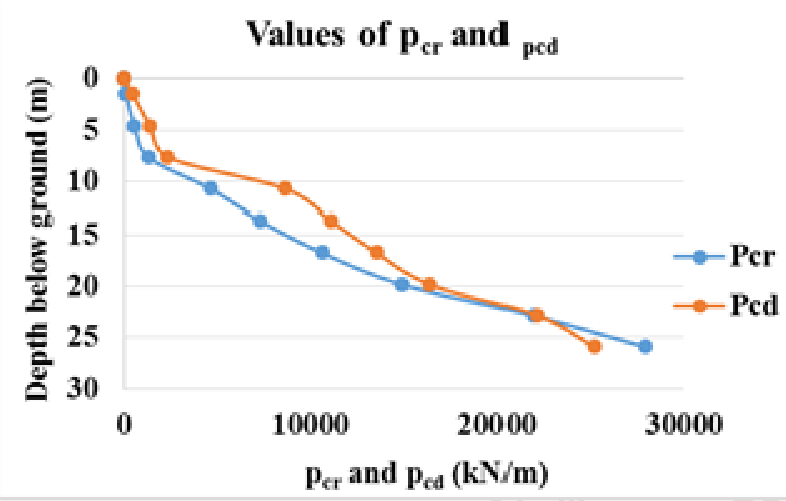

Fig. 3 Critical depth

Above the critical depth, $\mathrm{p}_{\mathrm{cr}}$ is taken for soil resistance and $\mathrm{p}_{\mathrm{cd}}$ is taken below the critical depth for $\mathrm{p}-\mathrm{y}$ curves [2]. The evaluation of critical depth to develop p-y curves are shown in Fig. 3. The developments of $p-y$ curves for single pile of selected case study pile group are presented in Fig. 4.

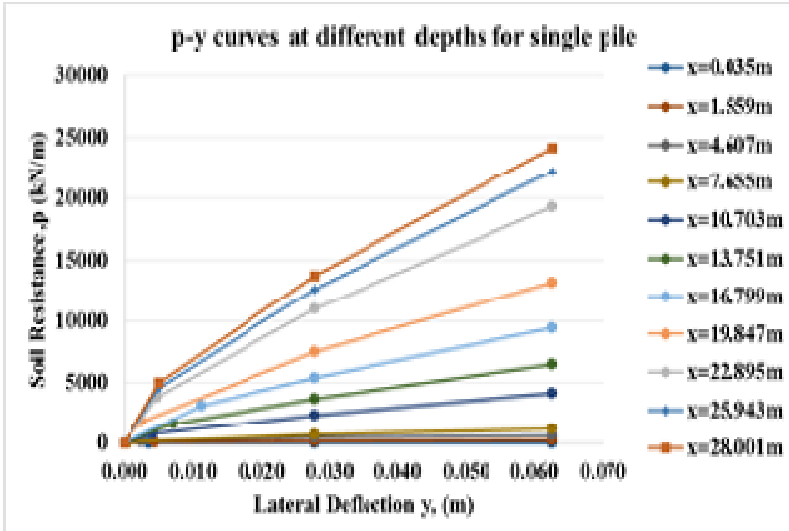

Fig. 4 p-y curves for single pile

Evaluations of p-y curves for pile-group are determined by applying P-multipliers $\mathrm{P}_{\mathrm{m}}$ [5]. The development of $\mathrm{p}$-y curves for transverse direction and longitudinal direction of group piles are shown in Fig. 5. p-y curves at different depths for pile group (Longitudinal)

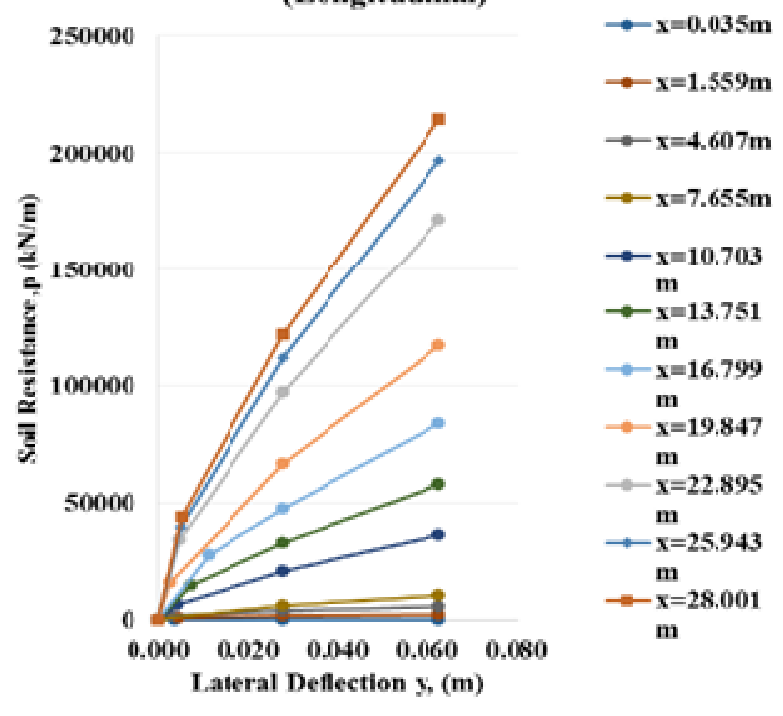

(a)

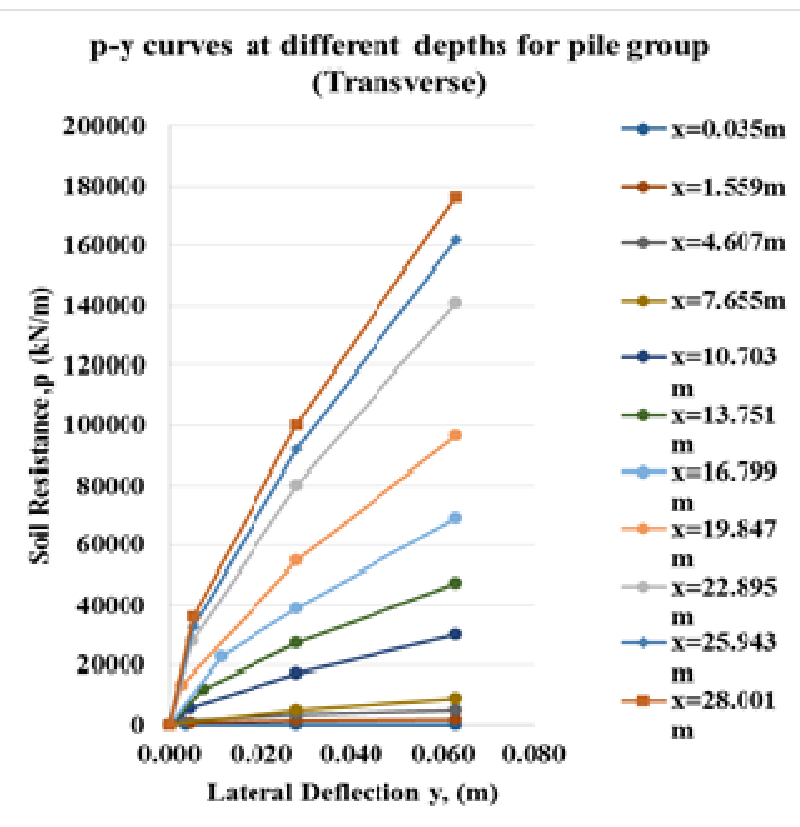

(b)

Fig. 5 p-y curves for (a) longitudinal direction and (b) transverse direction

\section{B. P-y Curves of Laterally Loaded Piles in Cohesionless Soils for Dynamic Condition}

The dynamic, single pile p-y curves were fit with an analytical expression, which appears to be valid for soft to stiff clay and loose to dense sand [5]. That expression is given below;

$$
p_{d}=p\left[\alpha+\beta a_{0}^{2}+k a_{0}\left(\frac{w y}{D}\right)^{n}\right]
$$

where,

$\mathrm{p}_{\mathrm{d}} \quad=$ dynamic value of $\mathrm{p}$ on the $\mathrm{p}-\mathrm{y}$ curve at depth $\mathrm{x}$

$\mathrm{p}_{\mathrm{s}} \quad=$ corresponding reaction on the static $\mathrm{p}-\mathrm{y}$ curve at depth $x$

$\mathrm{a}_{\mathrm{o}} \quad$ = frequency of loading, expressed in dimensionless terms $\omega \mathrm{r}_{\mathrm{o}} / \mathrm{V}_{\mathrm{s}}$;

$\omega=$ circular frequency of loading equal to $2 \pi \mathrm{f}$

$\mathrm{y} \quad=$ lateral pile deflection relative to the soil at depth $\mathrm{x}$

$\mathrm{D} \quad=$ pile diameter $(\mathrm{m})$ 
$\alpha, \beta, \kappa$ and $\mathrm{n}$ are constants determined from curve fitting. In dynamic analysis, $\mathrm{p}-\mathrm{y}$ curves are considered at $1^{\text {st }}, 4^{\text {th }}, 10^{\text {th }}$ and $30^{\text {th }}$ frequencies in soil-foundation interaction model with Chauk earthquake ground motion in longitudinal, transverse and vertical directions.

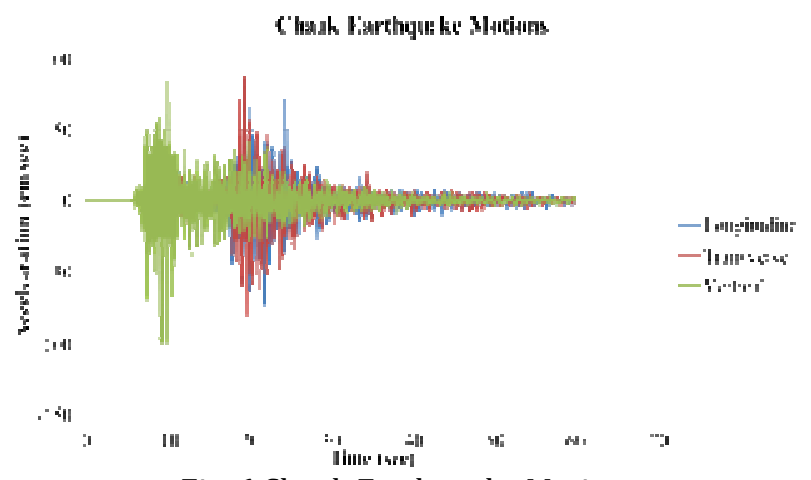

Fig. 6 Chauk Earthquake Motions

\section{SOIL-FOUNDATION INTERACTION}

In the 3D soil modelling, the stiffness of the elastic surrounding soil is well accounted. The size of the soil model is $122 \mathrm{~m} \times 122 \mathrm{~m} \times 48 \mathrm{~m}$. The layered soil conditions are modelled using design parameters presented in Table IV and possion's ratio for sand is considered as 0.3 for all layers. The concrete pile tube is considered to behave linearly elastic and modelled as a cylindrical structure. The material properties of pile group are as follows: $E=25 \mathrm{GPa}, \gamma=23.58$ $\mathrm{kN} / \mathrm{m}^{3}$ and $\mathrm{v}=0.2$.

The interaction between the sand and the pile was modelled by defining tangential and normal contact behaviour in the finite element model. The tangential contact between the two surfaces was defined using a friction coefficient (tan $(2 \phi / 3)$. The normal contact behavior of stiffness between the pile and soil was determined from p-y curves. The bottom of the pile and soil model was fixed and the exterior surface of the soil was constrained with multi-point constraints (MPC) constraints.

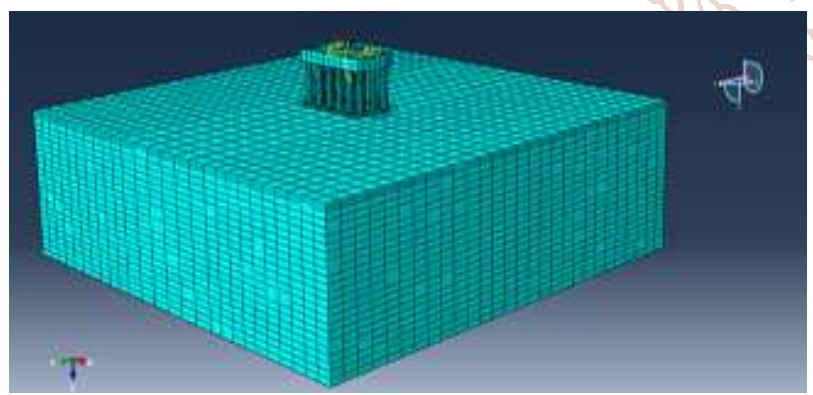

Fig. 7 Soil-foundation interaction finite element model

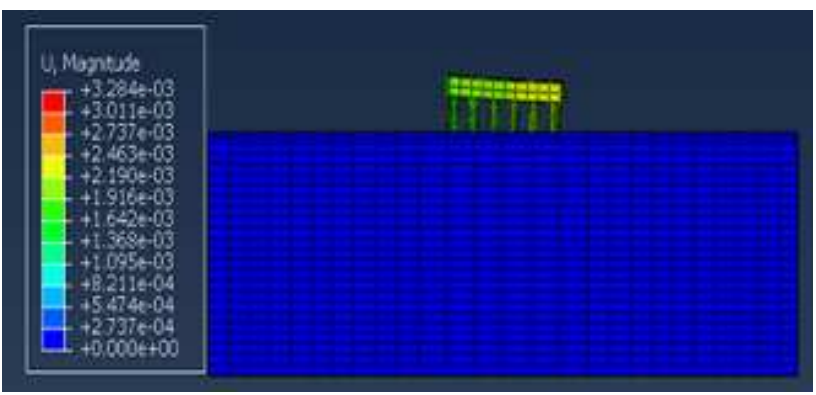

(a)

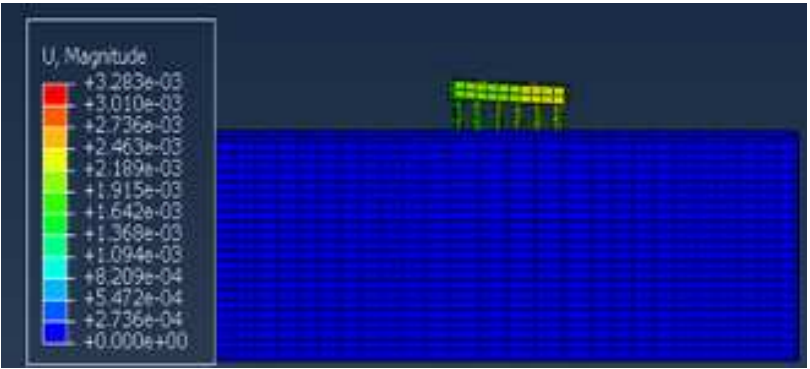

(b)

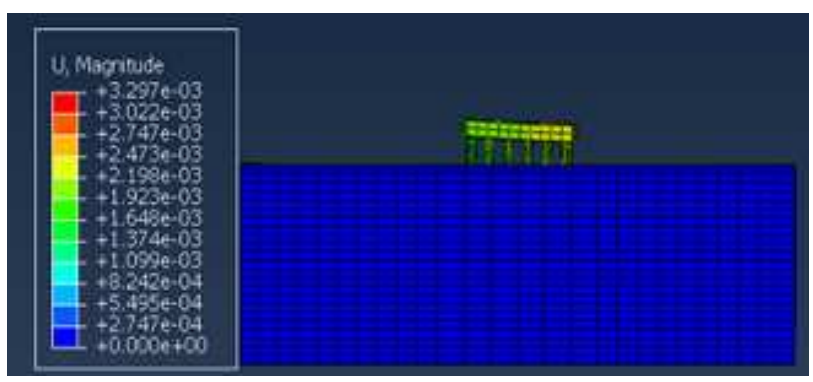

(c)

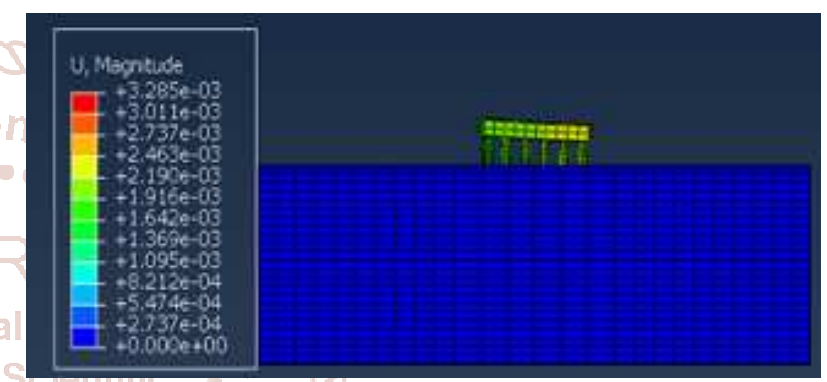

(d)

Fig.8 Soil-foundation interaction (a) static, and dynamic analysis with Chauk earthquake in (b) Longitudinal, (c)

Transverse and (d) Vertical direction with $0.12 \mathrm{~g}$ of Chauk 456-6470 Earthquake

In dynamic analysis in soil-foundation interaction, displacement in transverse direction of bridge is more than longitudinal and vertical direction of bridge in seismic excitations with Chauk earthquake ground motions. So, transverse direction of ground motion is considered with different frequencies.

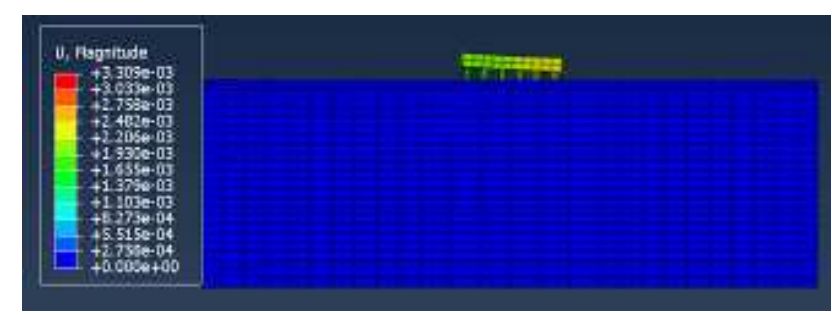

(a)

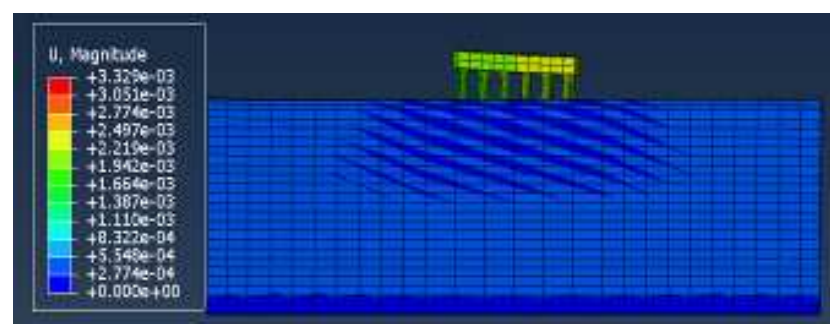

(b) 


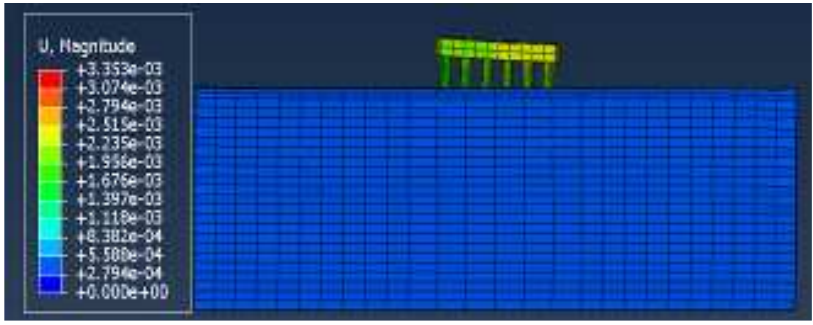

(c)

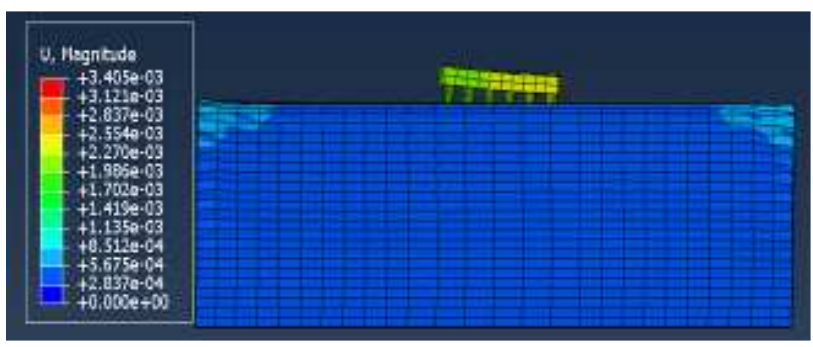

(d)

Fig.9 Soil-foundation interaction with earthquake excitation (a) $0.2 \mathrm{~g}$, and (b) $0.3 \mathrm{~g}$, (c) $0.4 \mathrm{~g}$ and (d) $0.5 \mathrm{~g}$ of Chauk Earthquake

A. Analysis Results of Soil-Foundation Interaction in Static and Dynamic Conditions

In static and dynamic conditions, maximum horizontal displacements are found in transverse direction of pier.

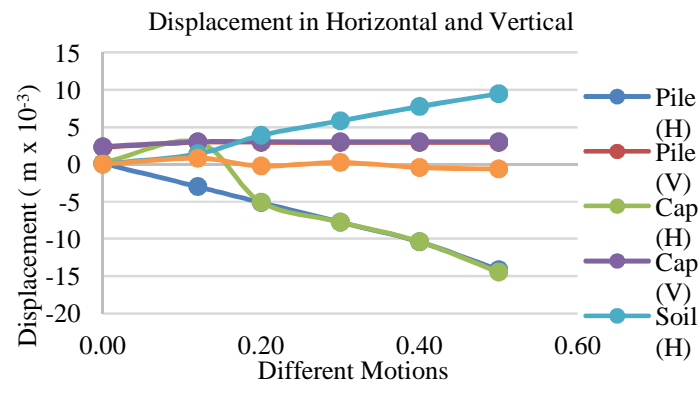

Fig.10 Comparison of static and dynamic analysis with different mode shapes of displacement of pile group and soil

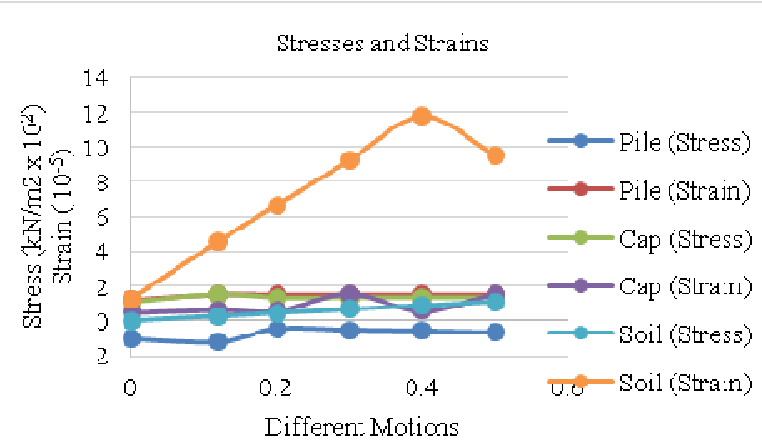

Fig.11 Comparison of static and dynamic analysis with different mode shapes (a) stresses and (b) strains

According to analysis results with different mode shapes, the result of the first mode shape is approximately same as the other mode shapes. So, first mode shape is considered all of ground motions of Chauk earthquake. According to the analysis results in static condition, it is found that the vertical and horizontal displacements at the pile tip are $2.28 \mathrm{~mm}$ and $0.14 \mathrm{~mm}$ respectively. In dynamic condition, the vertical and horizontal displacements at the pile tip are $3 \mathrm{~mm}$ and $2.94 \mathrm{~mm}$ are found at $0.12 \mathrm{~g}$. After that, maximum ground acceleration of $0.5 \mathrm{~g}$ is $14.5 \mathrm{~mm}$ and $2.94 \mathrm{~mm}$ in horizontal and vertical displacement of pile tip. Maximum shear stress and strain are found out the base of the pile cap.

\section{RESULTS AND DISCUSSIONS}

According to the soil investigation results presented Table II, the cohesion of soil, ' $c$ ' for every layer are zero and the internal friction angle of soil are ranging from $19.5^{\circ}$ to $30.5^{\circ}$. And then, soil resistance and deflection are determined for p-y curves. The p-y curves are developed for longitudinal and transverse directions of the foundation under studied pier. Due to the pile group configuration, the resistances of soil in transverse direction are less than longitudinal direction shown in Fig. 5. After developing the p-y curves, static and dynamic response of the soil-foundation interaction are carried out using ABAQUS. The analysis results are provided in Figs. 8 and 9. As shown in Fig. 9, the maximum displacements of the foundation of the pile cap in static and dynamic analysis are $0.2 \mathrm{~mm}$ and $14.4 \mathrm{~mm}$ in horizontal direction of static and dynamic. And then, the maximum deflection of 0.14 and $14.5 \mathrm{~mm}$ are found out at the pile tip in longitudinal direction. On the other hand, the maximum vertical displacement of $2.28 \mathrm{~mm}$ and $3 \mathrm{~mm}$ are found out at the pile tip. Due to the analysis results, the maximum principle stress and strain are found out at the base of the pile cap. The values of maximum principle stress and strain are $106658 \mathrm{~N} / \mathrm{m}^{2}$ and $4.8 \times 10^{-6}$ in static. And then, $130900 \mathrm{~N} / \mathrm{m}^{2}$ and $5.84 \times 10^{-6} \mathrm{in}$ dynamic of $0.5 \mathrm{~g}$ are found out respectively. Maximum and minimum principle stress and strain are found at the same region of the base of the pile cap and they are relating each other.

\section{CONCLUSION}

This study focuses on the behaviour of soil-foundation interaction under a bridge pier, and the selected case study is pier number 5 (PR5) under the bridge of the middle span in Pakokku Bridge. According to the analysis results, the deflection of longitudinal direction is larger than transverse direction and the maximum deflection of $0.14 \mathrm{~mm}$ and 14.5 $\mathrm{mm}$ are found out at the pile tip in longitudinal direction of static and dynamic condition of $0.5 \mathrm{~g}$. The maximum vertical displacement or settlement of $2.28 \mathrm{~mm}$ and $3 \mathrm{~mm}$ are found out at the pile tip. From AASHTO Standard Specifications for Highway Bridges, $\delta^{\prime} / \mathrm{L}$ shall be limited to 0.005 for simple span bridges and 0.004 for continuous span bridges in vertical displacement and maximum horizontal displacement is 1 in [3]. The values of maximum principle stress and strain are $106658 \mathrm{~N} / \mathrm{m}^{2}$ and $4.8 \times 10^{-6}$ in static. And then, $130900 \mathrm{~N} / \mathrm{m}^{2}$ and $5.84 \times 10^{-6}$ in dynamic of $0.5 \mathrm{~g}$ are found out respectively. In dynamic analysis, stress and strain in first mode are greater than the other mode shape. Finally it is found that the soil-foundation interaction under a bridge pier presented in this study is reliable and reasonable with the limitation of AASHTO Standard Specifications for Highway Bridges.

\section{ACKNOWLEDGMENT}

Firstly, the author wishes to acknowledge and thanks to all persons who kindly helped and supported her from beginning to finish. The author would like to express her great thanks to Department of Bridge, Ministry of Construction for supporting the necessary data. The author is sincerely thankful to all teachers, Department of Civil Engineering, Yangon Technological University. 


\section{REFERENCES}

[1] LU.C.W, GUI.M.W, and LAI.S.C "A numerical study on soil-group-pile-bridge-pier interaction under the effect of earthquake loading," Journal of Earthquake and Tsunami, 2014, VOL.8, No.1, 1_35.

[2] S. Prakash, and H. D. Sharma, Pile Foundations in Engineering Practice. John Wiley \& Sons, Inc, 1990.

[3] AASHTO (1977). Standard Specifications for Highway Bridges. 16th Edition (1996 with 1997 interims). American Association of State Highway and Transportation Officials, Washington, DC.
[4] S. Helwany, Applied Soil Mechanics With Abaqus Applications. John Wiley \& Sons, Inc, 2007.

[5] Browm, D.A., O’Neill, M.W., Hoit, M., Nagger, E.H., Vay, M.M., and Charkraborty, S. 2001. Static and Dynamic Lateral Loading of Pile Groups. NCHRP Report. No.461.

[6] Reese, L. C. and Matlock, H., Non-dimensional Solutions for Laterally Loaded Piles with Soil Modulus Assumed Proportional to Depth, Proceedings 8th Texas Coference on Soil Mechanics and Foundation Engineering, Austin, TX, 1956, pp. 1-41.

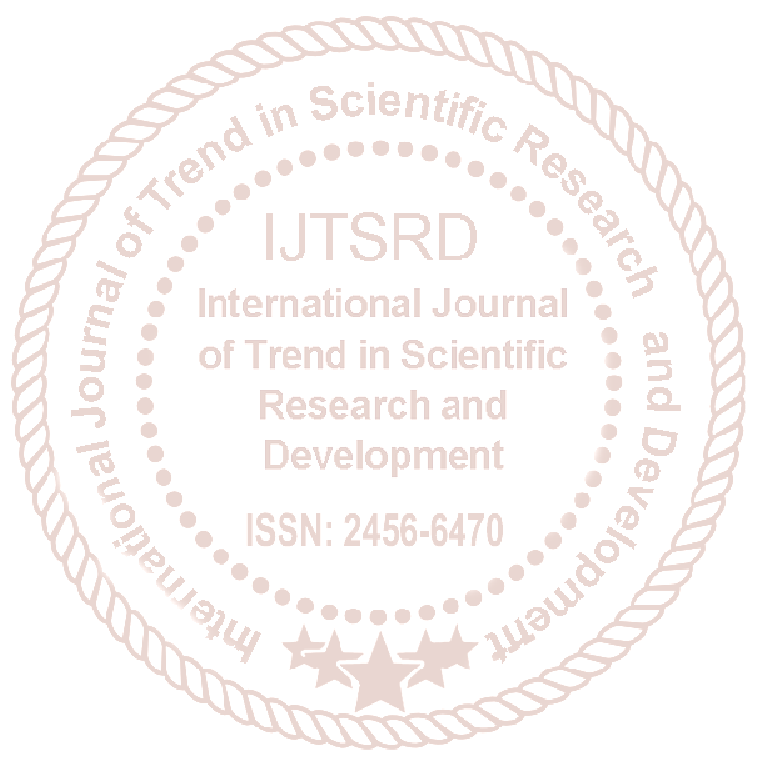

